\title{
Potpore za kućanstva s djecom
}

\author{
IVICA URBAN, Institut za javne financije
}

\section{UvoD}

Država izdvaja značajna sredstva za naknade namijenjene kućanstvima s djecom. Ciljevi tih naknada su ublažavanje rizika od siromaštva obitelji s djecom, ujednačavanje njihova standarda s kućanstvima koja nemaju djecu, ali i poticanje građana da imaju više djece.

Najpoznatije su naknade doplatak za djecu, rodiljne i roditeljske naknade te jednokratne pomoći pri rođenju djeteta. Osim toga, unutar zajamčene minimalne naknade nalazi se dio namijenjen djeci. Međutim, novčana pomoć kućanstvima s djecom ostvaruje se ne samo socijalnim naknadama već i poreznim olakšicama. Tako u sustavu poreza na dohodak postoji osobni odbitak za djecu kojim se smanjuje porezna obveza obveznika koji uzdržava jedno ili više djece.

Ovaj rad se bavi doplatkom za djecu, dijelom zajamčene minimalne naknade koji se odnosi na djecu $i$ osobnim odbitkom za djecu. Novčani iznosi koje iz tih izvora ostvaruju kućanstva s djecom ovdje se nazivaju potporama za djecu. Iznosi tih potpora ovise o dohotku kućanstva, odnosno potpore su funkcije dohotka. Izračunavajući te funkcije i crtajući njihove grafove za hipotetička kućanstva, mogu se uočiti zanimljive međuovisnosti, obrasci i nepravilnosti kod pojedinih potpora i za skup u cjelini.

Glavni problem ovoga skupa potpora za djecu leži u "stupnjevitom” dizajnu doplatka za djecu, kod kojeg se javljaju velike promjene iznosa potpore uslijed samo male promjene dohotka. Ako dohodak kućanstva prijeđe određenu granicu za samo jednu kunu, doplatak se smanjuje i za nekoliko stotina kuna. Takve "skokove" trebalo bi ublažiti ili ukloniti, a u ovom radu nudi se ilustrativni primjer reforme kojom se to može učiniti.

\section{MODEL ZA IZRAČUN POTPORA}

Iznosi potpora za djecu izračunavaju se za hipotetička kućanstva koja se razlikuju po strukturi članova i razini neto dohotka. Analizirane su dvije skupine kućanstava: (a) kućanstva A - s dvoje odraslih i dvoje djece, $\mathrm{i}(\mathrm{b})$ kućanstva $\mathrm{B}-\mathrm{s}$ dvoje odraslih i troje djece. 
Odrasli članovi kućanstva su majka i otac, a djeca su osnovnoškolske dobi. ${ }^{I}$ Razlikuju se sljedeći koncepti dohotka: (a) dohodak prije oporezivanja jest dohodak koji se oporezuje porezom na dohodak; (b) dohodak nakon oporezivanja ili neto dohodak jednak je dohotku prije oporezivanja umanjenom za porez na dohodak i prirez; (c) neto dohodak kućanstva je zbroj neto dohodaka svih članova kućanstva; (d) raspoloživi dohodak kućanstva je zbroj neto dohotka kućanstva, zajamčene minimalne naknade i doplatka za djecu. Neto dohodak po članu kućanstva (NDČK) je neto dohodak kućanstva podijeljen s brojem članova kućanstva. Dva odrasla člana unutar svakog kućanstva ostvaruju jednak dohodak prije oporezivanja. Kod oporezivanja porezom na dohodak osobni odbitak za djecu ravnomjerno se dijeli između dvaju odraslih članova. Primjenjuje se opći porezni raspored s tri stope (I2, 25 i 40\%). Stopa prireza je I2\%. Kućanstva se nalaze izvan potpomognutih područja.

\section{ZAJAMǦENA MINIMALNA NAKNADA}

Zajamčena minimalna naknada (ZMN) je temeljna socijalna naknada namijenjena ublažavanju siromaštva. ${ }^{2}$ Pripada kućanstvima koja zadovoljavaju dohodovni i imovinski cenzus.

Kako bi se izračunalo koliki iznos ZMN-a može ostvariti neko kućanstvo, prvo treba odrediti ”temeljni iznos" naknade, koji ovisi o broju i obilježjima članova kućanstva. Za kućanstva s dva odrasla člana, svakom odraslom članu pripada 480 kuna, a svakom djetetu 320 kuna. Dakle, za kućanstva A, koja imaju dva odrasla člana i dva djeteta, temeljni iznos je I.6oo (2 x 480 + 2 x 320) kuna. Tablica I prikazuje temeljne iznose za najčešće tipove kućanstava.

\section{Tablica I.}

Temeljni iznosi zajamčene minimalne naknade za neke vrste kućanstava (u kunama)

\begin{tabular}{lcc} 
Struktura kućanstva & Osnovni iznos ZMN-a \\
\hline Jedan odrasli član (samac) & 800 \\
\hline Jedan odrasli član i jedno dijete & I.I2O \\
\hline Dva odrasla člana & 960 \\
\hline Dva odrasla člana i jedno dijete & $\mathrm{I} .28 \mathrm{O}$ \\
\hline Dva odrasla člana i dva djeteta & $\mathrm{I} .60 \mathrm{O}$ \\
\hline Dva odrasla člana i tri djeteta & $\mathrm{I} .92 \mathrm{O}$ \\
\hline Izvor: autorov izračun
\end{tabular}

Izvor: autorov izračun

Kako bi se izračunao iznos ZMN-a, od temeljnog iznosa oduzme se ostvareni neto dohodak kućanstva. U priloženom primjeru, ako je neto dohodak kućanstva jednak nula, ZMN iznosi I.6oo kuna, odnosno jednak je temeljnom iznosu. Ako je neto dohodak I.ooo kuna, ZMN iznosi 600 kuna. Ako neto dohodak iznosi I.6oo ili više kuna, ZMN je jednak nula.

U ovom dijelu analize ne promatra se cjelokupni iznos ZMN-a, već samo dio koji se dobiva za djecu. Kućanstva A s neto dohotkom od nula kuna ostvaruju ZMN od I.6oo kuna, a od toga se na djecu odnosi 640 kuna, odnosno 40\% ukupnoga iznosa. Kućanstva B mogu ostvariti ZMN od najviše I.920 kuna, a za djecu se pritom dobiva 960 kuna, odnosno 50\% ukupnoga iznosa.

Grafikon I prikazuje iznose ZMN-a za kućanstva A i B te pripadajuće dijelove za djecu. Crta označena s "Ukupno - kućanstva A (2 djeteta)" kazuje da iznos ZMN-a za kućanstva A jednolično pada s I.6oo kuna pri neto dohotku od o kuna pa sve do o kuna pri neto dohotku od I.6oo kuna. Crta "Za djecu kućanstva A (2 djeteta)” pokazuje da pripadajući dio za djecu (40\% ukupnoga iznosa ZMN-a) pada sa 640 kuna na o kuna.

\footnotetext{
${ }^{1}$ Te su pretpostavke uvedene radi jednostavnosti. Odrasli član može biti roditelj, posvojitelj, skrbnik, očuh/maćeha, baka/djed i bilo koja druga osoba koji uzdržava djecu. Djeca mogu biti predškolske, osnovnoškolske, srednjoškolske dobi ili studenti u visokoškolskom obrazovanju. Za detalje o definicijama odraslih članova i djece vidjeti Zakon od doplatku za djecu, Zakon o socijalnoj skrbi i Zakon o porezu na dohodak.

${ }^{2}$ ZMN je uveden u siječnju 20I4., a zamijenit će pomoć za uzdržavanje. Za više informacija o ZMN-u vidjeti Zakon o socijalnoj skrbi i informacije na stranicama Ministarstva socijalne politike i mladih.
} 


\section{Grafikon I.}

Zajamčena minimalna naknada u zavisnosti o neto dohotku kućanstva (u kunama)

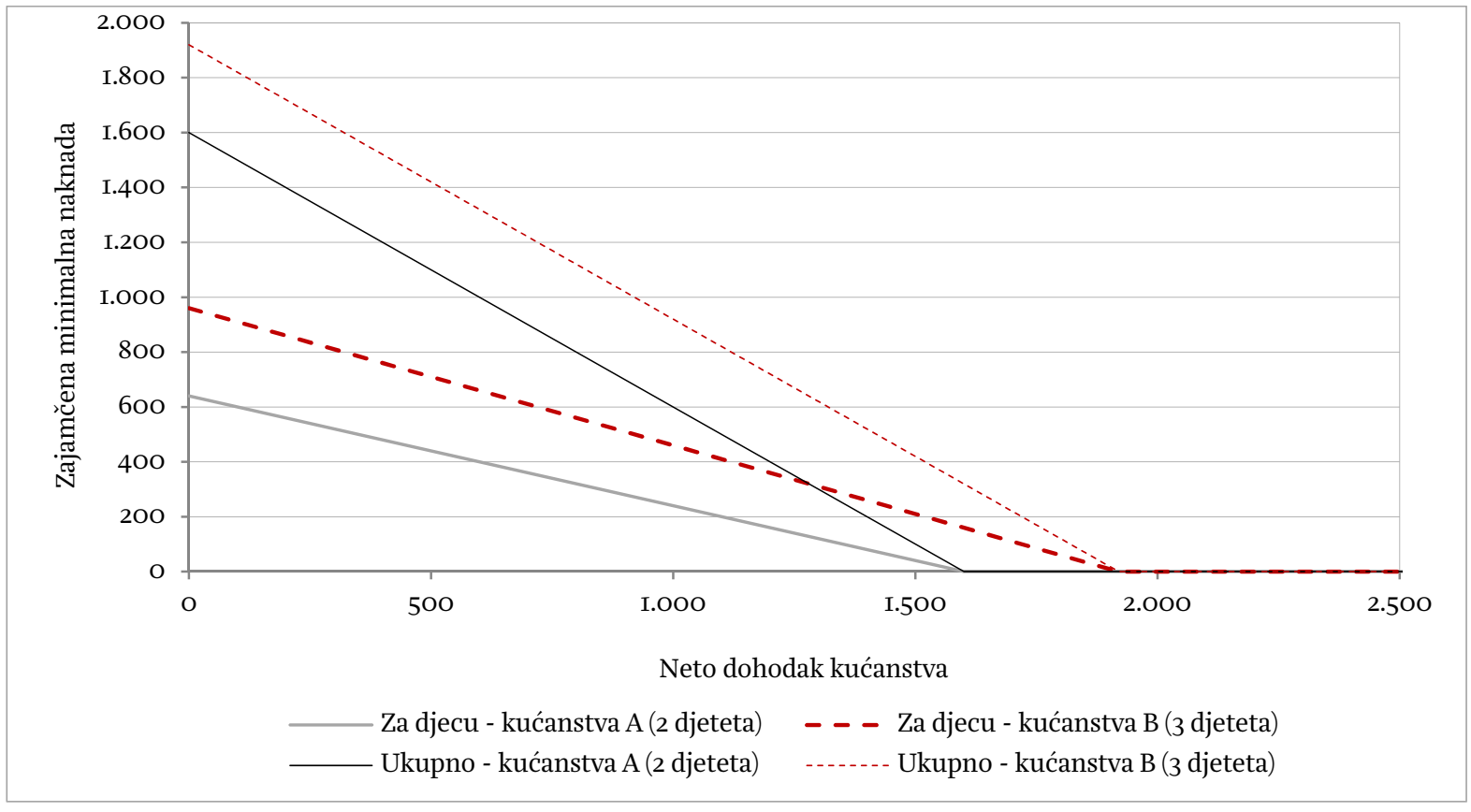

Izvor: autorov izračun

Slično vrijedi i za kućanstva B, za koja pripadajući dio za djecu (50\% ukupnoga iznosa ZMN-a), prikazan crtom "Za djecu - kućanstva B (3 djeteta)", pada s 900 kuna na o kuna.

\section{DOPLATAK ZA DJEGU}

Doplatak za djecu (DOPD) je socijalno-populacijska naknada namijenjena kućanstvima s djecom koja zadovoljavaju određeni dohodovni cenzus. Za razliku od ZMN-a, kod DOPD-a se ne provjerava imovinski cenzus.

Iznos DOPD-a sastoji se od "osnovnog dijela" i dodatka za kućanstva s troje ili više djece. ${ }^{3}$ Osnovni dio dobiva se kao umnožak broja djece i određenog iznosa koji ovisi o NDČK-u. Kako prikazuje tablica 2, ako je NDČK između o i 543 kune, broj djece množi se s iznosom od 299 kuna. ${ }^{4}$ Ako je NDČK između 543 i I.I2o kuna, iznos je jednak 249 kuna, a ako je NDČK između I.I2o i I.663 kune, iznos s kojim se množi broj djece jednak je 200 kuna.

\section{Tablica 2.}

Osnovni dio doplatka za djecu (u kunama)

\begin{tabular}{ccc} 
NDČK & Osnovni dio DOPD-a \\
\hline O do 543 & $299 \times$ broj djece \\
\hline 543 do I.I2O & $249 \times$ broj djece \\
\hline I.I2O do I.663 & 200 x broj djece \\
\hline više od I.663 & O \\
\hline
\end{tabular}

Izvor: autorov izračun

Ako je NDČK niži od I.663 kune, a kućanstvo ima tri djeteta, osnovnom dijelu pridodaje se dodatak od 500 kuna. Također, ako je NDČK niži od I.663 kune, a u kućanstvu je četvero ili više djece, osnovnom

\footnotetext{
${ }^{3}$ Iznos doplatka uvećava se i za djecu bez jednog ili oba roditelja te za djecu s oštećenjem zdravlja. Za više informacija o DOPD-u vidjeti Zakon o doplatku za djecu i informacije na stranicama HZMO-a.

${ }^{4}$ Svi iznosi su zaokruženi radi jednostavnosti.
} 
dijelu pridodaje se dodatak od I.ooo kuna. Dodatak za kućanstva s troje ili više djece uobičajeno se zove „pronatalitetni dodatak“ iako Zakon o doplatku za djecu za nj ne definira posebni naziv. ${ }^{5}$

Kao primjer se može uzeti kućanstvo koje se sastoji od dvoje odraslih i troje djece, a ima ukupni neto dohodak od 7.50o kuna. Slijedi da je NDČK jednak I.50o kuna, pa kućanstvo ulazi u razred od I.I2O do I.663 kune. Osnovni dio pritom iznosi 600 kuna ( 3 x 200 kuna), a tome se pridodaje 500 kuna jer kućanstvo ima tri djeteta. Dakle, DOPD za ovo kućanstvo je I.Ioo kuna, što se može vidjeti u tablici 3.

Tablica 3.

Ukupni doplatak za djecu ( u kunama)

\begin{tabular}{|c|c|c|c|c|c|}
\hline \multirow{2}{*}{ NDČK } & \multicolumn{5}{|c|}{ Broj djece } \\
\hline & $\mathrm{I}$ & 2 & 3 & 4 & 5 \\
\hline o do 543 & 299 & 598 & I.397 & 2.196 & 2.495 \\
\hline 543 do I.I2O & 249 & 498 & I.247 & I.996 & 2.245 \\
\hline I.I2O do I.663 & 200 & 400 & I.IOO & I.800 & 2.000 \\
\hline više od I.663 & $\mathrm{O}$ & $\mathrm{O}$ & $\mathrm{O}$ & $\mathrm{O}$ & $\mathrm{O}$ \\
\hline
\end{tabular}

Izvor: autorov izračun

Grafikon 2 prikazuje zavisnost DOPD-a o neto dohotku kućanstva. Pogledajmo prvo DOPD za kućanstva iz skupine A (dva odrasla člana s dvoje djece). Ako je neto dohodak kućanstva niži od 2.I73 kune, DOPD iznosi 600 kuna. Za dohodak između 2.173 i 4.478 kuna DOPD iznosi 500 kuna, a ako je neto dohodak između 4.478 i 6.652 kune, DOPD je jednak 400 kuna.

\section{Grafikon 2.}

Doplatak za djecu (DOPD) u zavisnosti o neto dohotku kućanstva (u kunama)

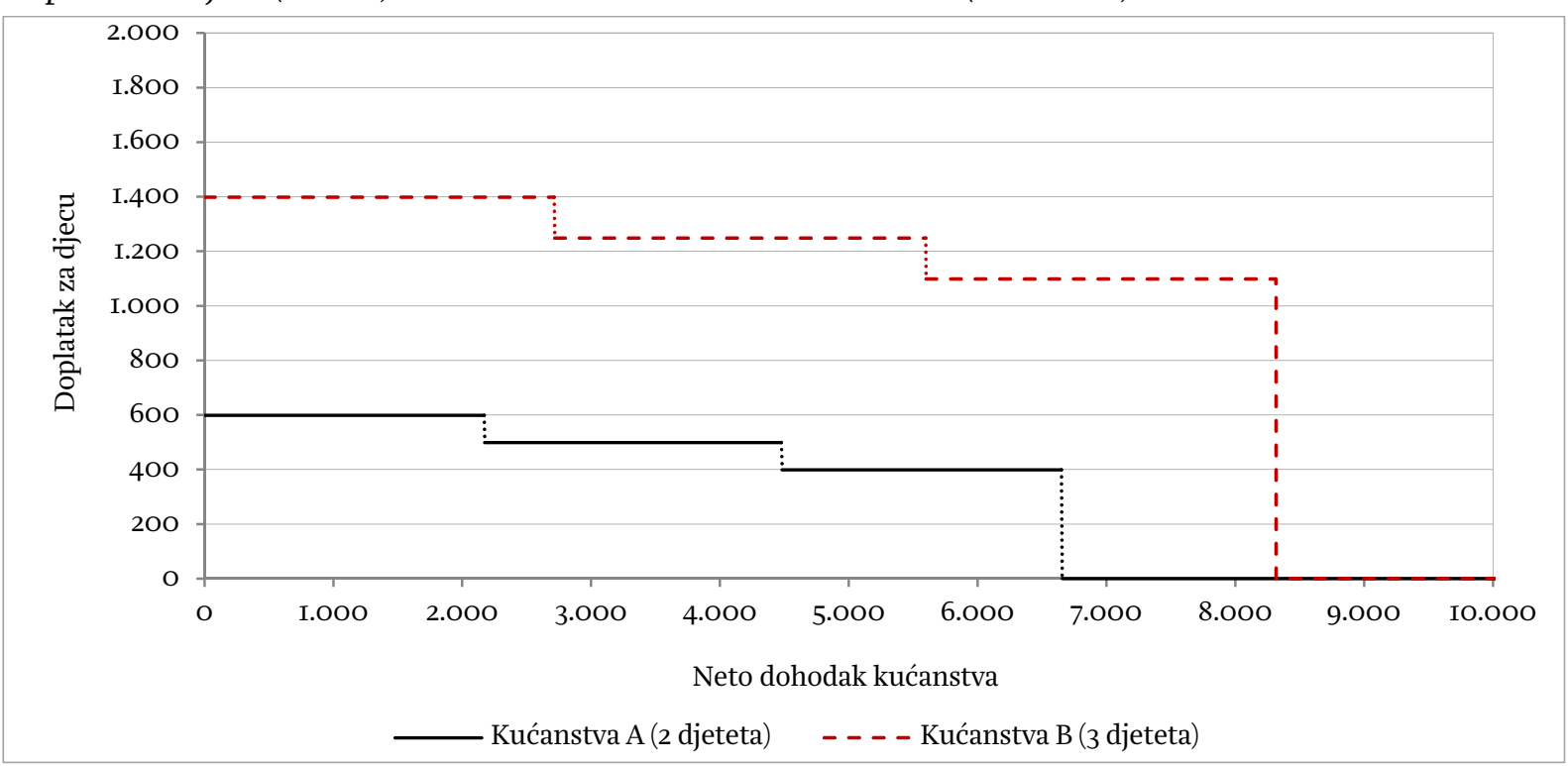

Izvor: autorov izračun

Graf funkcije DOPD-a je ”stupnjevit”, kako je prikazano na grafikonu 2. Funkcija nije neprekidna, kako bi je definirali matematičari, već ima točke u kojima se vrijednost naglo mijenja. Naime, ako je dohodak obitelji samo jednu kunu veći od neke od graničnih vrijednosti, iznos DOPD-a se smanjuje za Ioo ili više kuna. U primjeru kućanstva AI, čiji je neto dohodak 6.65I kunu, i kućanstva A2, čiji je dohodak samo dvije kune veći, dakle 6.653 kune, kućanstvo AI dobit će DOPD od 400 kuna, a kućanstvo A2 neće dobiti ništa!

5 Uvođenje "pronatalitetnog dodatka" početkom 2007. potaklo je na jednom internetskom forumu zanimljivu raspravu, u kojoj su nagoviješteni i neki rezultati ove analize 
U ovakvim situacijama "zaraditi više" znači u konačnici "dobiti manje", pa su osobe potaknute smanjiti svoj dohodak za određeni iznos kako bi dobile veći doplatak za djecu i ukupno ostvarile veći raspoloživi dohodak. Primjerice, osoba iz kućanstva A2 mogla bi zamoliti svog poslodavca da joj smanji dohodak za 5 kuna: tada bi ostvarila DOPD od 400 kuna te bi bila na dobitku od 395 kuna. Također, ovakav raspored krši načelo horizontalne jednakosti po kojemu bi približno jednaka kućanstva (po strukturi članova i razini dohotka) trebala dobivati približno jednake iznose naknade.

Za kućanstva iz skupine B (dva odrasla člana s troje djece) graf funkcije na grafikonu 2 sličnog je oblika, ali je "rastegnutiji” jer kućanstva u ovom slučaju imaju 5 članova, za razliku od kućanstava A koja imaju 4 člana. Iznosi za kućanstva B značajno su viši jer ona dobivaju "pronatalitetni dodatak". Međutim, nagli padovi iznosa DOPD-a sada su još izrazitiji. Naprimjer, kućanstva Bı i B2 imaju neto dohodak od 8.3I4 kuna, odnosno 8.3I6 kuna. Kućanstvo Bi dobiva DOPD od I.Ioo kuna, a B2 dobiva nula kuna.

\section{UMANJENI POREZ NA DOHODAK I PRIREZ ZBOG OSOBNOG ODBITKA ZA DJEGU}

Treći instrument koji se ovdje analizira je umanjeni porez na dohodak i prirez zahvaljujući odbitku za djecu. ${ }^{6}$ Odbitak za djecu je porezna olakšica koja umanjuje osnovicu poreza na dohodak, a mogu je ostvariti obveznici koji uzdržavaju djecu. Mjesečni odbitak za djecu iznosi I.Ioo kuna za prvo dijete, I.540 kuna za drugo dijete, 2.200 kuna za treće dijete, itd. Naprimjer, kao što prikazuje tablica 4, odbitak za obitelj s dvoje djece iznosi 2.640 kuna, a za obitelj s petero djece I2.Ioo kuna.

\section{Tablica 4.}

Iznosi odbitka za djecu (u kunama)

\begin{tabular}{ccc} 
Broj djece & Odbitak za djecu \\
\hline $\mathrm{O}$ & $\mathrm{O}$ \\
\hline $\mathrm{I}$ & $\mathrm{I.IOO}$ \\
\hline 2 & 2.640 \\
\hline 3 & 4.840 \\
\hline 4 & 7.920 \\
\hline 5 & $\mathrm{I} 2 . \mathrm{OOO}$ \\
\hline
\end{tabular}

Izvor: autorov izračun

Kao što je već spomenuto, odbitak za djecu pripada odraslim osobama koje uzdržavaju djecu. U ovoj analizi to su dva odrasla člana kućanstva, koja dijele odbitak za djecu na dva jednaka dijela. ${ }^{7}$ Kod kućanstava A (s dvoje djece), svaki će član iskoristiti polovicu od iznosa od 2.640 kuna, odnosno I.320 kuna. Kod kućanstava B (s troje djece) odrasli će članovi podijeliti iznos od 4.840 kuna te će svaki ostvariti 2.420 kuna.

Osim toga, svakom odraslom članu, kao obvezniku poreza na dohodak, pripada 2.200 kuna osnovnog osobnog odbitka. To znači da će ukupni osobni odbitak - koji je zbroj osnovnog osobnog odbitka i odbitka za djecu - za svakog odraslog člana u kućanstvima A iznositi 4.520 kuna (2.200 + I.320 kuna), odnosno 4.620 kuna $(2.200$ + 2.420 kuna $)$ za svakog odraslog člana u kućanstvima B.

Porezna osnovica je jednaka dohotku prije oporezivanja, umanjenom za ukupni osobni odbitak. Kako prikazuje tablica 5, donjih 2.200 kuna porezne osnovice množi se stopom od I2\%. Sljedećih 6.6oo kuna množi se stopom od 25\%, a dio osnovice iznad 8.800 kuna, stopom od 40\%. Tri umnoška se zbrajaju u obvezu poreza na dohodak.

\footnotetext{
${ }^{6}$ Ovdje su prikazana samo neka pravila poreza na dohodak. Za više detalja vidjeti Zakon o porezu na dohodak i web stranice Porezne uprave.

7 U ovom modelu oba odrasla člana imaju jednak dohodak prije oporezivanja, pa je u tom slučaju za kućanstvo optimalno podijeliti odbitak za djecu na dva jednaka dijela. No, mogući su i drugi obrasci podjele, ovisno o razini dohotka. Naprimjer, ako jedan uzdržavatelj zarađuje znatno više od drugoga, može biti optimalno da prvi uzdržavatelj sâm iskoristi cjelokupni odbitak za djecu.
} 
Tablica 5.

Porezni razredi i stope poreza na dohodak

\begin{tabular}{cc} 
Mjesečna porezna osnovica (u kunama) & Stopa $(\mathbf{u} \%)$ \\
\hline od o do 2.200 & I2 \\
\hline od 2.200 do 8.800 & 25 \\
\hline iznad 8.800 & 40 \\
\hline
\end{tabular}

Izvor: autorov izračun

Kako na poreznu obvezu utječe povećanje osobnoga odbitka, odnosno smanjenje porezne osnovice? Uzmimo za primjer obveznike V i Z, čiji su dohoci prije oporezivanja 6.00o i 20.000 kuna, a osobni odbitak za oba iznosi po 5.00o kuna. Njihove osnovice jednake su I.00o, odnosno I5.0oo kuna. Porez na dohodak osobe V jednak je I.OOO x O,I2 = I2O kuna. Porez osobe Z jednak je 2.200 x 0,I2 + 6.600 x $0,25+6.200 \times 0,4=4.394$ kune.

Zamislimo da se osnovica obaju obveznika smanjuje za Ioo kuna, pa sada za osobu V iznosi goo kuna, a za osobu Z I4.90o kuna. Porez na dohodak osobe V sada je Io8 kuna. Dakle, smanjio se samo za I2 kuna. Porez osobe Z iznosi 2.200 x 0,12 + 6.600 x 0,25 + 6.100 x 0,4 = 4.354 kune, što je 40 kuna manje od početnoga iznosa. U izračunu poreza izmijenio se samo iznos koji se množi stopom od 40\%, što nam govori da je smanjenje osnovice djelovalo samo na gornji dio osnovice, onaj koji se množi sa stopom od 40\%. U tome leži zaključak ovoga primjera: kod promjena osobnog odbitka stopa koja igra glavnu ulogu je najviša granična stopa koja zahvaća određenog obveznika. Za osobu V to je $12 \%$, a za osobu Z to je $40 \%$.

Konačno, prirez porezu na dohodak izračunava se kao umnožak stope prireza i obveze poreza na dohodak. U ovim primjerima stopa prireza je $12 \%{ }^{8}$

\section{Grafikon 3.}

Umanjeni porez na dohodak i prirez zbog odbitka za djecu (u kunama)

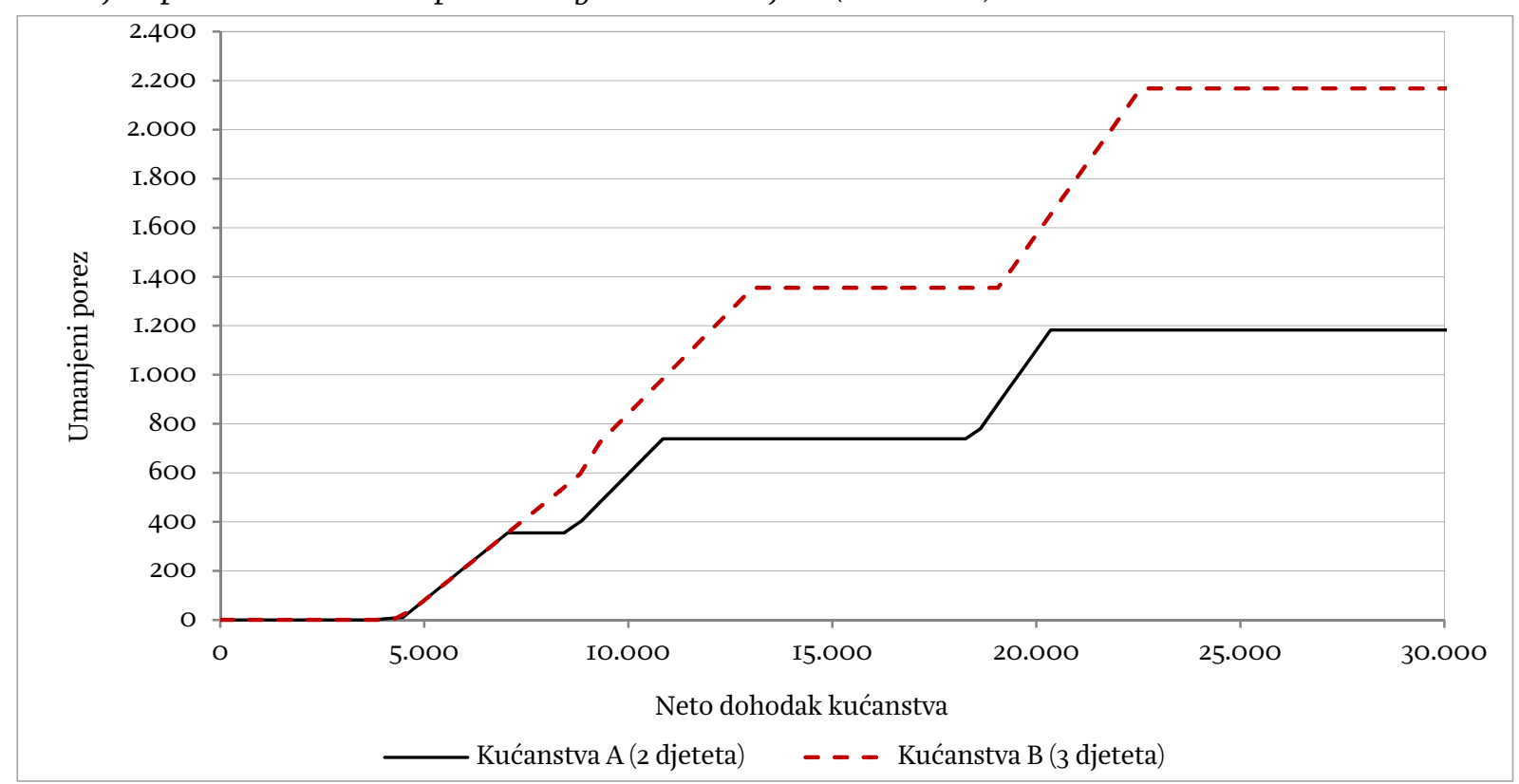

Izvor: autorov izračun

Grafikon 3 prikazuje smanjenja poreza i prireza koja ostvaruju kućanstva A i B zahvaljujući odbitku za djecu, u velikom rasponu neto dohodaka kućanstva, od o do 30.000 kuna. Za kućanstva s neto dohotkom manjim od 4.800 kuna nema gotovo nikakve uštede jer obveznici s tako niskim dohocima

\footnotetext{
${ }^{8}$ Stopu prireza određuju gradovi i općine u zadanim okvirima. Vidjeti web stranice Porezne uprave.
} 
ne iskorištavaju u potpunosti niti osnovni osobni odbitak. ${ }^{9} \mathrm{U}$ intervalu od 4.800 do 7.040 kuna ušteda raste do 355 kuna i jednaka je za kućanstva A i B. Iznad 7.040 kuna uštede rastu za oba tipa obitelji, ali brže za kućanstva B jer ona imaju pravo na veći osobni odbitak za djecu. Gornji iznos uštede za kućanstva A je I.I83 kune, a za kućanstva B je 2.168 kuna.

I kod ove potpore se mogu uočiti skokovite promjene iznosa. Naprimjer, kod kućanstava skupine A, pri neto dohotku od 8.425 kuna potpora iznosi 355 kuna, a kod neto dohotka od Io.85o kuna, iznos potpore je 740 kuna. Dakle, pri promjeni dohotka od $28 \%$, potpora se mijenja za Io8\%. Nagli porast potpore posljedica je prelaska u porezni razred koji se oporezuje višom graničnom stopom.

\section{UKUPNE POTPORE ZA DJEGU}

Koristeći informacije prikazane u prethodnim grafikonima, zbrajaju se iznosi triju potpora kako bi se dobila ukupna potpora za djecu. To se čini za svaku razinu neto dohotka kućanstva i za obje skupine kućanstava, čime se dobiva grafikon 4. Grafovi funkcija ukupne potpore za djecu za kućanstva A i B imaju sličan oblik.

\section{Grafikon 4.}

Ukupna potpora za djecu (u kunama)

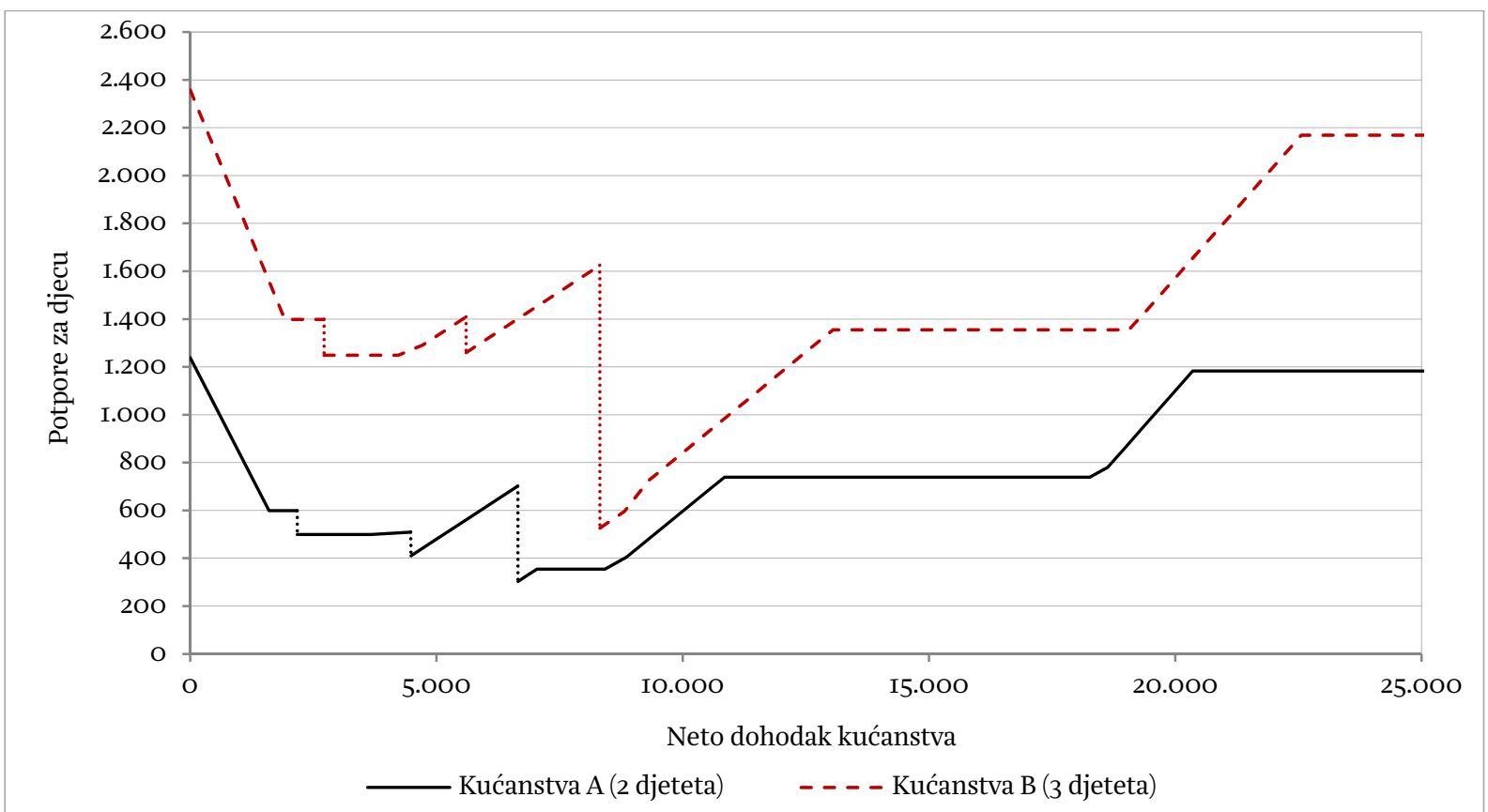

Izvor: autorov izračun

Analizirajmo prvo graf za kućanstva A. Kada je neto dohodak jednak nuli, ukupna potpora za djecu iznosi I.240 kuna, a zatim se naglo smanjuje - zbog prirode ZMN-a i DOPD-a - te pri dohotku od 2.200 kuna iznosi 500 kuna. Kod neto dohotka od 4.500 kuna ukupna potpora iznosi 400 kuna, a zatim raste sve do 700 kuna jer počinje djelovanje osobnog odbitka za djecu. Međutim, pri dohotku od 6.653 kuna, uočava se pad na samo 300 kuna, što je posljedica naglog nestanka DOPD-a. Nakon toga, kod neto dohotka od oko 8.500 kuna, ukupna potpora za djecu počinje rasti zahvaljujući osobnom odbitku, što je već uočeno na grafikonu 3.

\footnotetext{
9 Ukupni dohodak kućanstva od 4.800 kuna otprilike odgovara dvjema plaćama od 2.400 kuna (nakon doprinosa iz plaće). Oduzimanjem osnovnog osobnog odbitka od 2.200 kuna, dobiva se osnovica od 200 kuna koja se zatim oporezuje stopom od I2\%. Dakle, porez na dohodak s prirezom za jednog obveznika je 27 kuna, odnosno 54 kune za par.
} 
Kod kućanstva B se zamjećuje gotovo isti obrazac, ali je pad ukupne potpore u točki potpunog nestanka DOPD-a, pri neto dohotku od 8.316 kuna puno izraženiji - s I.625 na 526 kuna - odnosno za čak I.o9g kuna. Zanimljivo je promotriti razliku između ukupne potpore za kućanstva A i B, koja se može nazvati "poticajem za treće dijete". Njegov iznos prilično varira. Pri neto dohotku od nula kuna "poticaj" iznosi I.I2O kuna, zatim pada na 700 kuna pri neto dohotku od 6.653 kune, a onda se na intervalu neto dohotka od 6.700 do 8.315 kuna kreće između I.Ioo i I.3Oo kuna. Nakon toga, na prilično širokom intervalu od 8.316 do Io.85o kuna, iznosi tek oko 200 kuna, a zatim ponovno raste.

\section{Grafikon 5.}

Dohodak prije oporezivanja i raspoloživi dohodak kućanstva (u kunama)

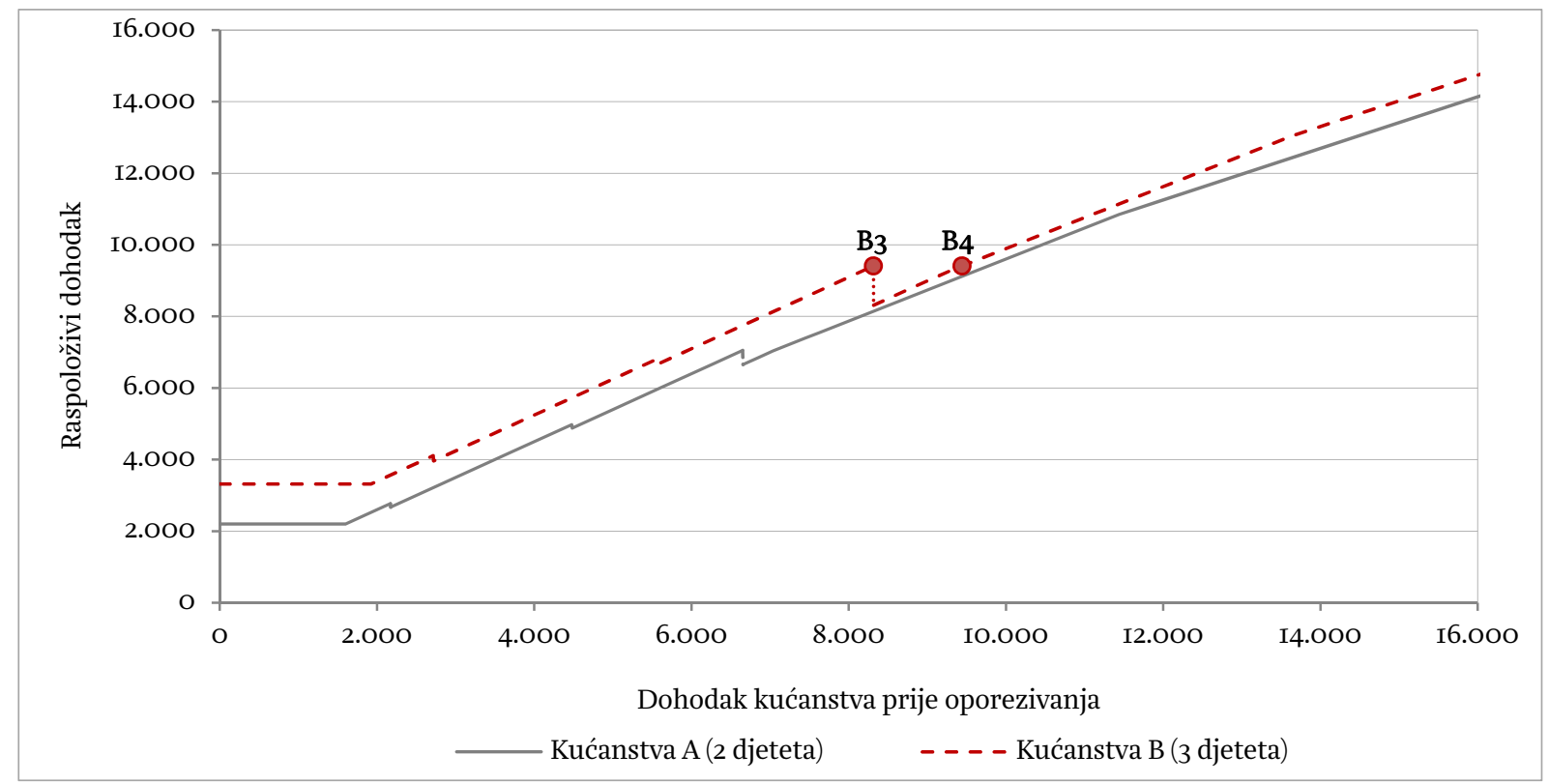

Izvor: autorov izračun

\section{RASPOLOŽIVI DOHODAK KUĆANSTVA}

Grafikon 5 prikazuje zavisnost između dohotka prije oporezivanja i raspoloživa dohotka. Na nekoliko mjesta se dade uočiti da grafovi funkcija nisu glatki, a to je posljedica, kako je već ranije napomenuto, stupnjevitog dizajna DOPD-a. Promotrimo dva kućanstva iz skupine B, i to kućanstvo B3 s dohotkom prije oporezivanja od 8.3I4 kuna i B4 s dohotkom prije oporezivanja od 9.440 kuna. Iako je kućanstvo B4 na tržištu zaradilo I.I26 kuna više od kućanstva B3, njihov raspoloživi dohodak je jednak i iznosi 9.4I3 kuna.

\section{"IZGL_ADIVANJE FUNKGIJE" UKUPNE POTPORE ZA DJEGU}

Mogu li se nekako izgladiti lomovi i nepravilnosti u funkciji ukupne potpore za djecu (grafikon 4), čime bi se uklonila područja horizontalne nejednakosti? Može li se "poticaj za treće dijete” ujednačiti za kućanstva s različitim razinama dohotka?

Za ilustraciju se ovdje nudi simulacija reforme sustava kojom bi se riješila dva spomenuta problema. Reformom bi se istovremeno trebalo: (a) promijeniti doplatak za djecu tako da njegov iznos ne ovisi o razini dohotka; (b) ukinuti osobni odbitak za djecu; (c) graničnu stopu poreza na dohodak od $25 \%$ sniziti na $24 \%$, a stopu od $40 \%$ sniziti na $36 \%$. Pri tome bi ZMN ostao nepromijenjen.

U simuliranom sustavu, sva kućanstva s određenim brojem djece primala bi isti iznos DOPD-a, bez obzira na neto dohodak. Na taj bi način sva kućanstva A (s dvoje djece) primala iznos od 6oo kuna, a 


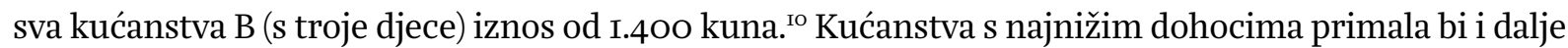
dio ZMN-a koji se odnosi na djecu. Budući da odbitka za djecu više nema, potpore za djecu sastoje se od dijela ZMN-a za djecu i DOPD-a.

Na grafikonu 6 se može vidjeti kako bi izgledali grafovi funkcija ukupne potpore za djecu u simuliranom sustavu u usporedbi sa stvarnim sustavom. U simuliranom sustavu kućanstva A s neto dohotkom od nula kuna primaju potpore za djecu od I.240 kuna (DOPD je 600 kuna, a ZMN za djecu je 640 kuna). Kućanstva B s neto dohotkom od nula kuna primaju 2.36o kuna (DOPD je I.40o kuna, a ZMN za djecu je 96o kuna). Zatim potpora za djecu lagano pada jer se smanjuje ZMN za djecu, koji je jednak nuli pri neto dohotku od I.6oo kuna za kućanstva A, odnosno I.92o kuna za kućanstva B. Dakle, za kućanstva s najnižim dohocima simulirani i stvarni sustav su identični.

Sva kućanstva A s neto dohotkom većim od r.6oo kuna imaju jednake potpore od 600 kuna, a sva kućanstva B s neto dohotkom iznad I.920 kuna imaju jednake potpore od I.4Oo kuna. U simuliranom sustavu nema naglih prekida grafa funkcije ukupne potpore za djecu. Razlika između naknade za kućanstva A i B, odnosno ”poticaj za treće dijete”, nepromjenjiv je za sve dohotke.

\section{Grafikon 6.}

Ukupna potpora za djecu u stvarnom i simuliranom sustavu (u kunama)

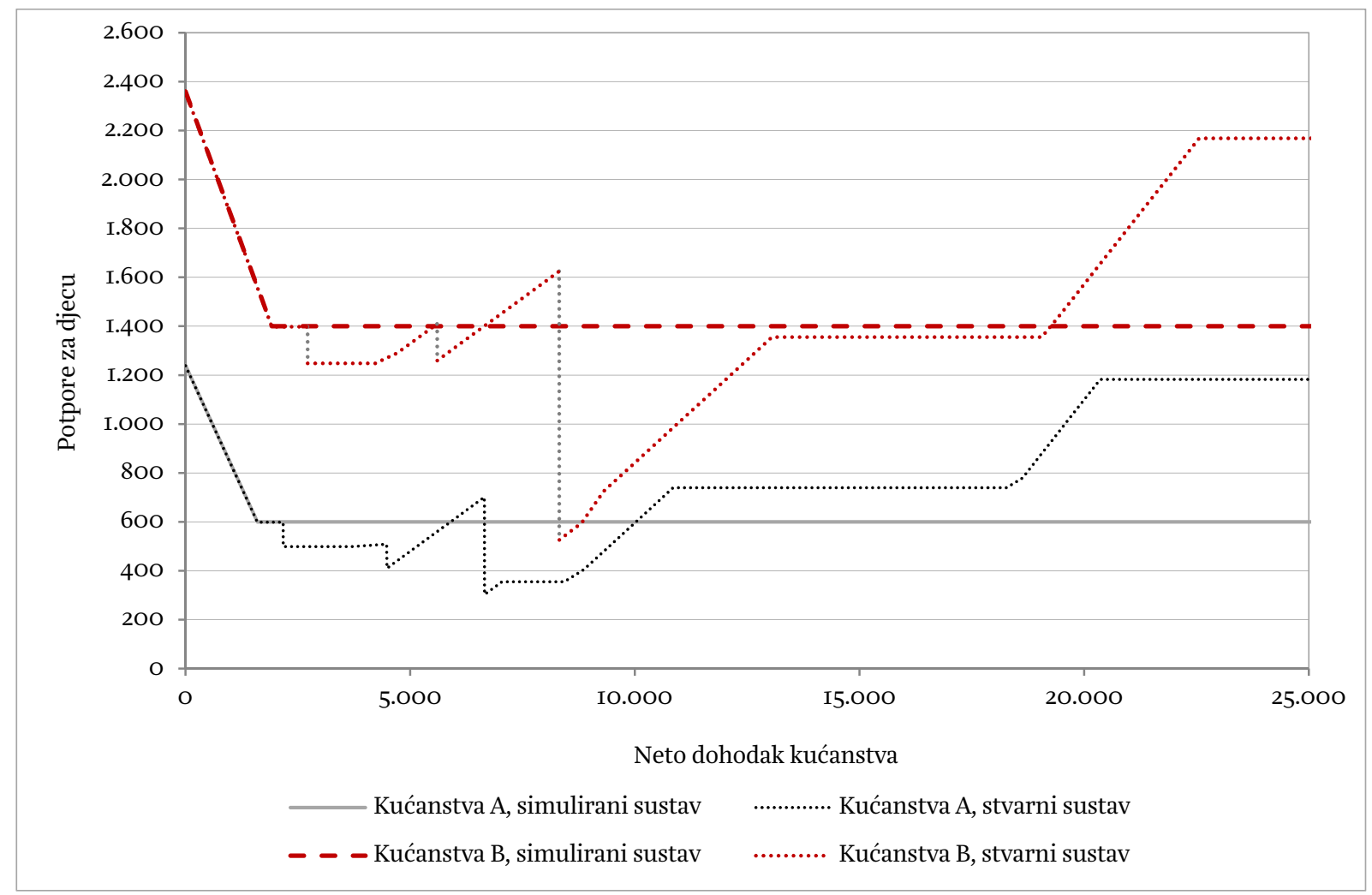

Izvor: autorov izračun

U simuliranom sustavu su i grafovi funkcija raspoloživa dohotka izglađeni, kao što prikazuje grafikon 7, na kojemu se može usporediti simulirani i stvarni sustav. "Dobitnici” u simuliranom sustavu su kućanstva A s dohotkom prije oporezivanja između 6.656 kuna i Io.640 kuna, te kućanstva B s neto dohotkom između 8.316 i I3.500 kuna.

Io Iznosi od 6oo, odnosno I.40o kuna odabrani su tako da otprilike odgovaraju prosječnom iznosu ukupnih potpora za djecu, isključujući ZMN. 
Naizgled, gubitnici u simuliranom sustavu su kućanstva s neto dohotkom iznad 20.ooo kuna. Kao što je ranije istaknuto, kućanstva A s neto dohotkom iznad 20.350 kuna ostvaruju potporu za djecu od I.I83 kune, a kućanstva B s neto dohotkom iznad 22.500 kuna ostvaruju 2.I68 kuna. Ukidanjem osobnog odbitka za djecu i uvođenjem dječje naknade, potpore za djecu padaju 583 kune za spomenuta kućanstva A, odnosno 768 kuna za spomenuta kućanstva B. Međutim, ovaj je gubitak kompenziran smanjenjem graničnih poreznih stopa u porezu na dohodak.

\section{Grafikon 7.}

Dohodak prije oporezivanja i raspoloživi dohodak u stvarnom i simuliranom sustavu (u kunama)

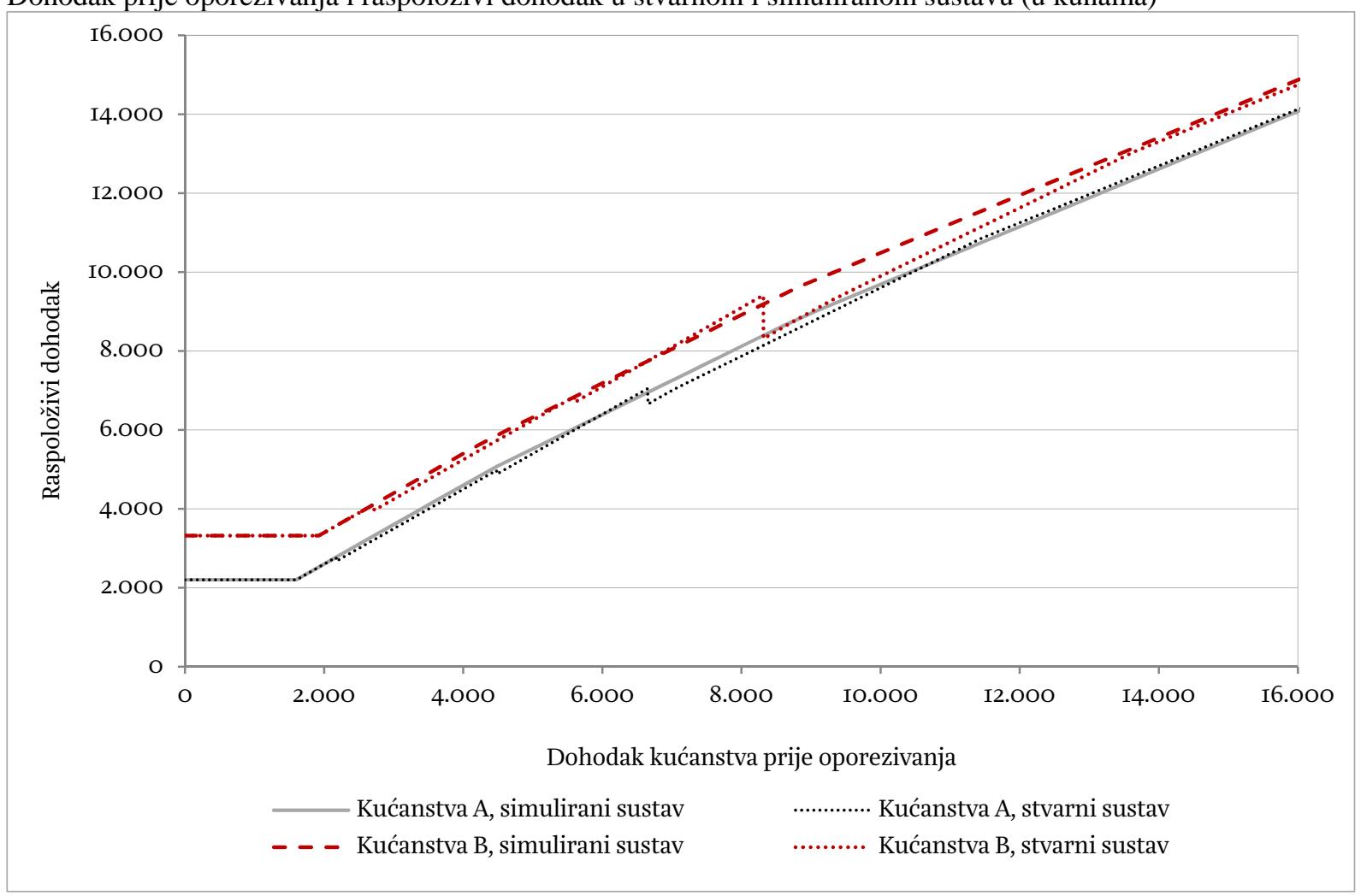

Izvor: autorov izračun

\section{ZAKLJUČAK}

U ovom je radu analizirano kako na proračune kućanstava s djecom djeluju tri instrumenta porezne i socijalne politike: doplatka za djecu, zajamčene minimalne naknade i osobnog odbitka za djecu. Iznosi koje od tih naknada i olakšica primaju kućanstva s djecom, nazvani su potporama za djecu. Iscrtani su grafovi funkcija pojedinih potpora i ukupne potpore, koji opisuju njihovu zavisnost o neto dohotku kućanstva.

Glavni problem ovog skupa potpora za djecu leži u "stupnjevitom" dizajnom doplatka za djecu, kod kojeg se javljaju velike promjene iznosa naknade uslijed samo male promjene dohotka. Najdojmljiviji primjer pružaju dva kućanstva s dvoje odraslih i troje djece. Neto dohodak prvog kućanstva je 8.3I4 kuna, a drugog 8.316 kuna. Doplatak za djecu prvog kućanstva iznosit će I.Ioo kuna, a drugog kućanstva nula kuna. Takve nagle promjene iznosa potpore donekle su prisutne i kod odbitka za djecu.

Kućanstva s djecom, pri svim razinama dohotka, primaju određeni iznos potpora za djecu. Ti iznosi značajno variraju, ovisno o razini neto dohotka. Za kućanstvo s dvoje djece ukupna potpora se kreće od 300 kuna (ako je neto dohodak kućanstva 6.652 kune), pa sve do I.20o kuna (ako je neto dohodak kućanstva o kuna ili je veći od 20.000 kuna). Za kućanstvo s troje djece, ukupna potpora za djecu se 
kreće od 526 kuna (ako je neto dohodak kućanstva jednak 8.316 kuna), pa sve do 2.ooo kuna i više (ako je neto dohodak kućanstva jednak o kuna ili je veći od 22.500 kuna).

Razlika u ukupnoj potpori za djecu između kućanstava s troje i s dvoje djece koja imaju jednak dohodak nazvana je "poticajem za treće dijete". Taj poticaj je vrlo neujednačen za različite neto dohotke i kreće se od samo 200 kuna na intervalu od 8.316 do Io.850 kuna, pa sve do I.30o kuna pri dohotku od 8.3I4 kuna.

Prikazani grafikoni mogu inspirirati različite zaključke i prijedloge o dizajnu i izdašnosti ZMN-a, DOPD-a i PD-a. Ono što se sa sigurnošću već sada može reći jest da je nužno "izgladiti” grafove funkcija potpora za djecu, odnosno ublažiti skokovite promjene njihovih iznosa. Stoga je radi ilustracije priložena simulacija jednostavne reforme sustava potpora za djecu kojom se uklanjaju negativni poticaji i horizontalna nejednakost, a ujednačuje se poticaj za treće dijete.

U reformi sustava važno je izbjeći djelomična i ad hoc rješenja. Stoga je grafikone, poput prikazanih u ovome radu, potrebno izraditi i za druge vrste kućanstava, primjerice za kućanstvo sa samohranim roditeljima. U scenarijima za kućanstva s tek rođenom djecom trebalo bi uključiti i rodiljne, roditeljske, i ostale naknade. Za simulaciju stvarnih učinaka reforme poreza i socijalnih naknada na životni standard građana i na državni proračun potrebno je upotrijebiti mikrosimulacijske modele poput miCROmoda. ${ }^{\text {II }}$

\section{LITERATURA}

Zakon o doplatku za djecu, NN 94/OI., I38/o6., I07/O7., 37/o8., 6I/II., II2/I2.

Zakon o porezu na dohodak NN I77/O4., 73/O8., 80/IO., II4/II., 22/I2., I44/I2., 43/I3., I2O/I3., I25/I3., I48/I3.

Zakon o socijalnoj skrbi, NN 157/13.

II Više o miCROmodu vidjeti na web stranicama Instituta za javne financije. 